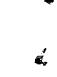

\title{
Statements by President Bill Clinton and the US Food and Drug Administration on regulations to restrict the marketing, sale, and distribution of tobacco to children
}

On 10 August 1995, President Bill Clinton announced that the US Food and Drug Administration $(F D A)$ was moving forward with regulations that would sharply curtail the advertising, promotion, sale, and distribution of tobacco products to minors. This action followed an investigation by the FDA as to whether tobacco products should be classified as drugs or drug delivery devices under the federal Food, Drug, and Cosmetic Act (FDCA). FDA regulation of tobacco products would require such a classification in the absence of new authorising legislation.

Some of the findings of the FDA investigation were presented in 1994 testimony to the US Congress and were reproduced in Tobacco Control (1994; 3: 148-58, 362-9). Several studies pertinent to the question of whether smokeless tobacco products should be regulated as drugs or drug delivery devices under the FDCA were published in the Spring 1995 issue of Tobacco Control (1995; 4 : 1-2, 57-79).

Given the unprecedented nature of the events surrounding the President's announcement we are reproducing several pertinent items here.

The text of President Clinton's August 10th statement, delivered at a press conference in the East Room of the White House, is reproduced below, along with a transcript of relevant questions and answers that followed his prepared remarks. The version below is based on a verbatim transcript prepared by fack $W$ Cannon from the actual speech; some extraneous words were deleted to clean up the syntax.

Following the President's remarks at the press conference, we have reproduced an interview conducted with the President on August 11th by the Music Television Network (MTV). The transcript of this interview was prepared by the United States Information Agency; once again, some extraneous words were deleted to improve the syntax. Portions unrelated to tobacco were also deleted.

Finally, we have reproduced four press releases issued by the FDA on the day of the President's press conference. These releases are entitled "Children and Tobacco: The Facts, The Problem, The Proposal, and What Others Say".

The full text of the proposed rule was published in the 11 August 1995 issue of the Federal Register (volume 60, No 155, pages 41314-75). $A$ document outlining the legal basis for the proposed rule, entitled "Nicotine in cigarettes and smokeless tobacco products is a drug and these products are nicotine delivery devices under the Federal Food, Drug, and Cosmetic Act", was published in the same issue of the Federal Register (pages 41454-787). The 11 August 1995 issue of the Federal Register may be purchased for $\$ 8$ from the Superintendent of Documents, US Government Printing Office (GPO), Washington, DC 20402, USA, tel +1 2025121800, fax +12025122250 (document No 069-001-00086-6). A set of appendices to the legal document may also be available from the GPO or from the Office of Policy (HF-23), Food and Drug Administration, 5600 Fishers Lane, Rockville, Maryland 20857, USA, tel +1 301 8273380, fax +13014436906 .

A detailed chronology of the developments leading up to the President's announcement will appear in the next issue of Tobacco Control $-\mathrm{ED}$

\section{White House Press Conference, 10 August 1995}

\section{President Clinton:}

Good afternoon. Today I am announcing broad executive action to protect the young people of the United States from the awful dangers of tobacco. Over the years, we have learned more and more about the dangers of addictive substances to our young people. In the ' 60 s and '70s, we came to realise the threat drugs pose to young Americans. In the ' 80 s we came to grips with the awful problem of drunk driving among young people. It is time to take a third step, to free our teenagers from addiction and dependency.
Adults are capable of making their own decisions about whether to smoke, but we all know that children are especially susceptible to the deadly temptation of tobacco and its skillful marketing. Today and every day this year, 3000 young people will begin to smoke; 1000 of them ultimately will die of cancer, emphysema, heart disease, and other diseases caused by smoking. That's more than a million vulnerable young people a year being hooked on nicotine that ultimately could kill them.

Therefore, by executive authority I will 


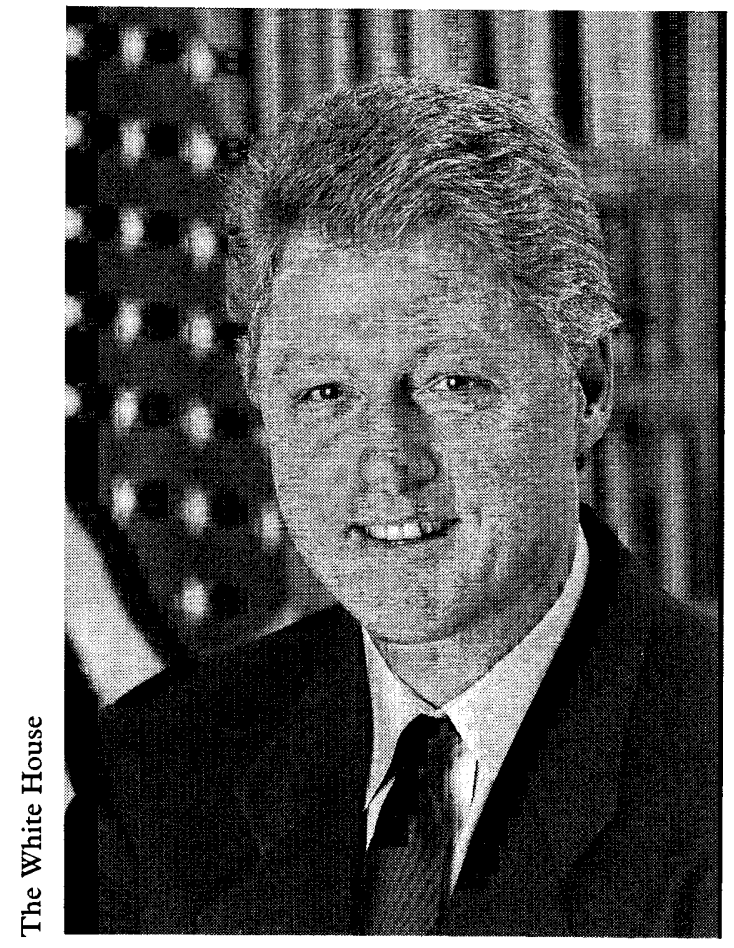

President Bill Clinton

restrict sharply the advertising, promotion, distribution, and marketing of cigarettes to teenagers. I do this on the basis of the best available scientific evidence: the findings of the American Medical Association, the American Cancer Society, the American Heart Association, the American Lung Association, the Centers for Disease Control [and Prevention]. Fourteen months of study by the Food and Drug Administration [FDA] confirms what we all know: Cigarettes and smokeless tobacco are harmful, highly addictive, and aggressively marketed to our young people.

The evidence is overwhelming, and the threat is immediate.

Our children face a health crisis that is getting worse. One third more eighth graders (13-14 years old) and one quarter more tenth graders (15-16 years old) are smoking today than four years ago. One out of five high school seniors (17-18 years old) is a daily smoker. We need to act, and we must act now before another generation of Americans is condemned to fight a difficult and grueling personal battle with an addiction that will cost millions of them their lives.

Adults make their own decisions about whether or not to smoke. Relatively few people start to smoke past their teens. Many adults have quit; many have tried and failed. But we all know that teenagers are especially susceptible to pressures: pressure to the manipulation of mass media advertising, the pressure of the seduction of skilled marketing campaigns aimed at exploiting their insecurities and uncertainties about life.

When Joe Camel tells young children that smoking is cool, when billboards tell teens that smoking will lead to true romance, when Virginia Slims tells adolescents that cigarettes may make them thin and glamorous, then our children need our wisdom, our guidance, and our experience. We're their parents, and it is up to us to protect them.

So today I am authorising the Food and Drug Administration to initiate a broad series of steps all designed to stop sales and marketing of cigarettes and smokeless tobacco to children. As a result the following steps will be taken:

* First, young people will have to prove their age with an ID card to buy cigarettes.

* Second, cigarette vending machines which circumvent any ban on sales to kids will be prohibited.

$\star$ Third, schools and playgrounds will be free of tobacco advertising on billboards in their neighborhoods.

* Fourth, images such as "Joe Camel" will not appear on billboards or in ads, in publications that reach substantial numbers of children and teens.

* Fifth, teens won't be targeted by any marketing gimmicks, ranging from single cigarette sales to $\mathrm{T}$-shirts, gym bags and sponsorship of sporting events.

* And finally, the tobacco industry must fund and implement an annual $\$ 150$ million campaign aimed at stopping teens from smoking through educational efforts.

Now these are all common-sense steps. They don't ban smoking, they don't bar advertising. We do not, in other words, seek to address activities that sell - that seek to sell cigarettes only to adults. We are stepping in to protect those who need our help-our vulnerable young people. And the evidence of increasing smoking in the last few years is plain and compelling.

Now, nobody much likes government regulation, and I would prefer it if we could have done this in some other way. The only other way I can think of is if Congress were to write these restrictions into law. They could do that, and if they do, this rule could become unnecessary. But it is wrong to believe that we can take a voluntary approach to this problem. In the absence of congressional action, and in the presence of a massive marketing and lobbying campaign by cigarette companies aimed at our children, clearly I have no alternative but to do everything I can to bring this assault to a halt.

The issue has touched all of us in personal ways. We all know friends or family members whose lives were shortened because of their involvement with tobacco. The vice president's sister, a heavy smoker who started as a teen, died of lung cancer. It is that kind of pain that I seek to spare other families and young children. Less smoking means less cancer, less illness, longer lives, a stronger America. Acting together we can make a difference. With this concerted plan, targeted at those practices that especially prey upon our children, we can save lives, and we will.

To those who produce and market cigarettes I say today: Take responsibility for your actions, sell your products only to adults, draw the line on children, show by your deeds as well as your words that you recognise that it is wrong as well as illegal to hook one million children a year on tobacco. 
Terence Hunt, Associated Press :

Mr President, with your decision on tobacco, you're taking on one of the biggest cash crops in a region where you've already got major political problems. Are you writing off the South in next year's elections, and isn't this a blow to other Democratic candidates in tobacco states?

\section{President Clinton:}

Well, first of all, the most important thing is that there is an epidemic among our children You've got a third more eighth graders (13-14 years old), a quarter more 10th graders (15-16 years old), smoking than there were 10 years ago. Whatever the political consequences, 1000 kids a day are beginning a habit which will probably shorten their lives. I mean, that is the issue. And I believe that is the issue everywhere. I believe there are tobacco farmers in the states which grow tobacco who have been involved in it 100 years or more - their families - who don't want their kids to start smoking. We're not talking about whether they have a right to grow tobacco or reap the paltry 4.5 cents, which is all they get out of a pack of cigarettes; we're talking about whether we are going to do what we know is the right thing to do to save the lives of America's children. And I think it is more important than any political consequences.

\section{Brit Hume, ABC News:}

$\mathrm{Mr}$ President, in view of the powerful evidence of the dangers of smoking which you cited, wouldn't it have been more logical to impose an outright ban instead of a regulatory partial step which has the effect of getting the federal government into the business of regulating the size of print in advertisements?

\section{President Clinton:}

Well first, I don't know that the federal government will regulate the size of print. We regulate the warning labels. And, of course, there is a proposal here on advertising to try to deal with restricting access to billboard advertising and others. But I think it would be wrong to ban cigarettes outright because, number one, it's not illegal for adults to use them. Tens of millions of adults do use them. And I think it would be [as] ineffective as Prohibition was.

But I think to focus on our children is the right thing to do. Cigarette use among, or purchasing of cigarettes by, young people children - is supposed to be illegal in all 50 states, but they do it regularly. These fine young people here were with me this morning, and one of them talked about how he bought cigarette pack after cigarette pack after cigarette pack out of vending machines to try to demonstrate to his local legislators that the laws were a sham.

These [regulations] will not make the laws a sham. This will enable us to save young people's lives.
Bill Plante, CBS News:

$\mathrm{Mr}$ President, given the fact that there's been a 20 year war against drugs, which are illegal for everybody, which has produced at best mixed results, given the fact that anybody who has kids knows that the more you prohibit something, the more attractive it often becomes, what makes you think that you can do any better in the war against cigarettes than we've done against drugs?

\section{President Clinton:}

Well, first of all, let me take on your premise here. There have been sustained periods of years in our country and in recent history when drug use has gone down in all categories of drugs among all ages of people without regard to race or income. Unfortunately, today the picture is somewhat mixed because casual drug use among young people seems to be going up in areas where they feel a certain level of hopelessness, and we intend to reassert our efforts there. But it's simply not true that cultural changes and legal bars together cannot work to reduce consumption.

With regard to cigarettes, we have seen cultural changes leading to reduction in consumption, but what we see among young people is adults quitting and young people increasing their usage. If you make it clearly illegal, more inaccessible, you reduce the lure of advertising and then you have an affirmative campaign, a positive campaign, so that you don't say, "Just say "no"", you give young people information, and you make it the smart, the cool, the hip thing to do to take care of yourself and keep yourself healthy and alive. I believe there is every evidence from what has happened in drugs and in many other areas that we will see a dramatic decline in smoking among young people. I think we can do that.

And I think, you see, there have been a lot of cultural changes to that effect in other areas. You see [that] some states that have done it right have big increases in the use of seat belts. And drunk driving goes down dramatically in some areas with a combination of the right sort of enforcement and the right sort of publicity.

So I just don't accept your premise. I think we'll have a big dent in this problem.

\section{Susan Page, Newsday:}

Mr President, you noted in your speech in Charlotte [North Carolina] yesterday that children follow what we do more than what we say. And I wonder what you think the message is when, on the one hand, the government cracks down on teen[age] smoking; on the other hand, it spends perhaps $\$ 25$ million a year subsidising the growth of tobacco, and when you yourself continue to smoke those big ol' cigars.

\section{President Clinton:}

Well, first of all, as you know, I'm allergic to cigars, so I don't smoke many anymore, but I smoke a handful a year, probably. And I 
probably shouldn't. And I try not to do it in any way that sets a bad example, but I plead guilty to that.

On the tobacco program, if it is selffinancing-now I've always supported the tobacco programme. It is essentially a selffinancing program. The question is, do you want this tobacco grown by family farmers, or do you want it grown by big corporations, if it's a self-financing program? I would not favor a large taxpayer outlay for it, but a selffinancing program, essentially - which is what that is - has been designed to preserve the structure of family farms and the culture of the family farms, rather than let the big tobacco companies grow it themselves and turn all those folks into hired hands.

I have thought, since it was going to be grown one way or the other, the family farm structure was a better one. I don't think that sends a signal that we think young people ought to smoke cigarettes.

Mike McKee, Conus Communications: Mr President, last week you said that you did not want to advance a tobacco strategy that would get caught up in the courts and prevent any kind of action from taking place for years. Now, you seem to have embarked on that strategy. Tobacco companies have already today filed suit against your proposals. Why did you determine [that] a voluntary effort in concert with the tobacco companies would not work, and is there any hope for some sort of compromise, either compromise with the tobacco companies or Congressional action, before you implement these regulations?

\section{President Clinton:}

Well, first of all, I had hoped that the tobacco companies would agree to support these restrictions and to put them in law. And it's still not too late for that. You know, the FDA - Dr Kessler - has announced today a rule making procedure on the assumption of [FDA] jurisdiction and on the specifics that $I$ just outlined. If the tobacco companies accept those and this Congress will write them into law, then you will not have a long regulatory proceeding. But you will have immediate effects. That is, if they would rather have a law than federal regulation, the FDA director, $\mathrm{Dr}$ Kessler, and I would rather have an immediate impact on teen smoking, not two years of litigation and then start the work. So it is not too late for that. But I am against a voluntary plan. I'm against it for several reasons.

First of all, there'd be no way to enforce it. Secondly, the history of voluntary agreements with the tobacco industry is not good, to put it mildly. And thirdly, even if they tried to adhere to it, I don't believe they could legally do so. Let me just give you one example. Suppose you were in the vending machine business and you sued the tobacco companies for deciding together that they were not going to let your vending machines go anywhere. Without a legal requirement, there's a good chance that could be held in a court of law to be a restraint of trade. So I think even if they tried to do it, they couldn't do it.

So we have to have a mandatory system, but I would just as soon have an act of Congress. Dr Kessler agrees because we've got an epidemic of teen smoking and far better to start right now as soon as we can pass a law than wait until we wade through all this litigation.

\section{Unidentified Reporter No 1:}

In going after teenage smoking, Mr. President, did you consider including alcohol abuse as part of that? I know you mentioned drunk driving in your opening remarks, but alcohol among young people is thought to be as much of a problem as smoking.

\section{President Clinton:}

But first of all, it [alcohol] is far less accessible, it's harder to get. And what we have advocated there, and I hope the Congress will adopt, is a national zero tolerance for alcohol among young drivers. If we go to zero tolerance among young drivers, I think it will make a difference.

Now, I noted last week and I'd like to give the state credit for it: One state adopted zero tolerance this last week. We are now up to 27 states that have done it on their own. But I think zero tolerance is the best thing to do.

\section{Unidentified Reporter No 2:}

$\mathrm{Mr}$ President, are you sure you wouldn't like to pledge today not to smoke cigars anymore to set an example?

\section{President Clinton:}

Well, you mean should I go from five or six down to zero a year? Maybe so, but I don't think that's the point. The point I want to make is, number one, cigars and pipes were not found by the FDA to be part of this. Did you know that? Number two, the issue for me is, I try to set a good example. I try never to do it where people see. I admitted that I did do it when Captain [Scott] O'Grady was found because I was so happy. It was a form of celebration. But I don't think that you should let that become the issue. The issue is whether the children are smoking cigarettes in this country.

\section{Carl Cannon, Baltimore Sun:}

The steps that you outlined today are tailored very carefully to curb the sale of tobacco to young people. My question is, if they're implemented, will the FDA retain power that would allow them at a future date to ban or curb the sale of tobacco to adults?

\section{President Clinton:}

Well of course that's what the tobacco companies are worried about, I guess. Our belief is 
that this is a pediatric disease. This is a problem for children, that when tobacco is lawful it would be wrong for a government agency to try to in any way restrict the access of adults to it, if it is lawful. I don't know what the law would be because I'm not the lawyer for the agency. I can't give you a lawful answer. I can tell you that the policy of this government is that the focus should be on our children, their health and their welfare. That is the focus.

If there is a worry underlying the question you ask, there is an answer to that worry - put it in the law. Let's have the tobacco companies come in. Let's talk to the members of Congress from the tobacco growing states. Let's pass it into law, pass these restrictions, put them into law, do it now. Then we won't have all these lawsuits and we will begin immediately, right now, to try to protect the children of this country. That is the answer.

\section{Unidentified Reporter No 3:}

Mr President, on the FDA rule again, a coalition of advertisers is filing suit today, saying that for a legal product your rule would go far beyond any precedent in restricting First Amendment [freedom of speech] rights. Is there any precedent that you could cite that would be equivalent in its reach into the First
Amendment? And if not, are you not concerned about that aspect?

\section{President Clinton:}

Well, first of all, nobody who's ever held this office loved the First Amendment any more than I do. And no one has ever felt both edges of it any more than I have. I believe in the First Amendment. That's what my speech about religious freedom was about the other day. I believe in it.

But I would remind you of just a few basic facts. It is illegal for children to smoke cigarettes. How, then, can it be legal for people to advertise to children to get them to smoke cigarettes? And does anybody seriously doubt that a lot of this advertisement is designed to reach children, so we get new customers for the tobacco companies as the old customers disappear? That it cannot be a violation of the freedom of speech in this country to say that you cannot advertise to entice people to do something which they cannot legally do?

So I just don't buy the First Amendment argument. It's just not true.

And by the way, that is why, to go back to an earlier question, the FDA ran the risk of having a rather complex rule to make it clear that there should be some freedom left, some considerable freedom left, to advertise to adults.

\section{Music Television Network (MTV) Interview with President Clinton, 11 August 1995}

Q: Mr. President, minors buy one billion packs of cigarettes a year. How are you going to make not smoking and quitting smoking cool and attractive to young people?

President Clinton: Well, I think we have to do several things. I think, first of all, the government's responsibility is to make sure that the young people understand that it's addictive and dangerous and can kill them, and that about one third of the young people who start smoking every day - about 1000 people a day, young people-will have their lives shortened because of it.

The second thing I think you have to do is make it less accessible. Then the third thing I think we have to do is make it less attractive that is, we need to change the advertising and limit the ability of advertising to be a lure.

We had a young teenager in here who was part of an anti-smoking group yesterday who said to me - I was so touched - she said, "We look at these ads", she said, "these girls smoking; they're always tall, they're always thin, they always have long hair, they're always pretty". She said, "It's just like when the boys who are young see a movie star holding a gun". And it was shocking what she said.

And then what we want the tobacco companies to do is to spend some money on an affirmative strategy to put out positive messages-over MTV, for example-about how it's cool not to smoke instead of to smoke. So I think you make it less accessible, less attractive, and then put out a positive message.

And, of course, we need a lot of help. We need people like you to do programs like this, and every parent in this country needs to talk to their children. All the parents need to talk to their children about it, because we now have done 14 months of careful research and we know how damaging this is, and we know that the tobacco companies know how damaging it is from their own files. We've got to do something about it.

Q: Do you worry about making smoking more enticing by making it more forbidden to young people?

President Clinton: I think that's always a concern. There could be some of that. But the staggering magnitude of the damage that it's doing is so great, I think if young people really understand how dangerous it really is and all the things that can happen to them and how it can affect their future, I don't think it will be more glamorous.

Q: You know, though, what kids are going to 
say. In a time where they're growing up and sex is associated with AIDS, alcohol with drunk driving, going out late at night you could be shot, it's very violent, smoking during your adolescence almost seems like a lesser evil.

President Clinton: I know it does, but in some ways it's the thing that puts them most at risk over the long run. And we have to do something about the other things, too. I've fought very hard to get the assault weapons out of the hands of gang members, to pass the Brady Bill, to put more police officers on the street. The crime rate is going down in almost every big city in this country. We're doing a better job trying to keep big shipments of drugs out of the country. We're working hard on that.

But this is a serious problem. On alcohol, it's less accessible than cigarettes. It's still a problem, but I want a zero-tolerance drunk driving law for young people in every state in the country, or here in the Congress. But the cigarettes - the magnitude of the damage caused is greater than all of that right now. And we just have to focus on it.

I know it-because there normally is a period of several years between the time you start and keep smoking and the time you face the consequences. And when you're young you think you're going to live forever. I know that it's going to be harder to get young people to focus on that. But we have to. There's a lot of destructive behavior in America we need to attack at the same time, and I just think that we can get these numbers way, way down.

You gave the number - a billion packs of cigarettes a year - we can get that way down. And when we do, we'll get the life expectancy of these young people and their quality of life way up.

Q: Did you ever experiment with cigarettes as a teen? Did you go through that phase?

President Clinton: I didn't. But I'm surprised I didn't, but I didn't. The reason I didn't is because my mother was a heavy smoker. She smoked a couple of packs of cigarettes a day until my daughter got her to quit for her eighth birthday. When my daughter turned eight, her grandmother gave her that for a present. So I had a bad feeling about it from childhood. But it was only because of that. I'm sure I would have done it otherwise.

Q: Why were you savvy enough to have a bad feeling about it? You didn't like the smell of the house, or you didn't like...

President Clinton: Yes, I didn't like the smell in the house. And it struck me as a bad habit, kind of a nervous habit, a reliance. And I had a feeling that it was not good for her health.

Q: What would you say to (your daughter) Chelsea if you saw her fall under peer pressure of some of her friends and start smoking, or if you found ashes in her bedroom in an ashtray or something?

President Clinton: I would talk to her about it and tell her I thought it was a bad idea. She's the most militant person in our house, though.

Q: Yes, it doesn't sound like you're worried. President Clinton: She and Hillary are always on me. You know, as I confessed yesterday, I still, once in a great while, maybe five, six, seven times a year, will smoke a cigar when I'm outside. They think that's awful - at all. And I've got to do better with it. But if they see me chewing one on the golf course or something, they're on me. So my family is doing a better job with it than I am.

Q: Some kids I talk to said that nothing but an outright ban on cigarettes would deter them. So why not a ban? Because cigarettes are just as deadly, if not more so, for adults.

President Clinton: They are, but they're not illegal. You have to go through all the same problems we went through with prohibition with liquor. It would have significant economic dislocations for a large number of Americans. And I think as a practical matter, because so many adults are, in effect, hooked on it, it would be very, very difficult to enforce.

What I want to do is to phase it out over time by getting young people (to) stop using cigarettes. Then eventually it will phase out. That would be my goal. I think we just have to start with our young people.

Q: Do you consider tobacco companies evil? President Clinton: I wouldn't go that far. I don't think that. And I certainly don't consider the tobacco farmers evil. I think they're good people. Most of them - a lot of them-come from families that have been doing it a hundred, sometimes two hundred years.

I think some of these companies have known for a long time, according to their own documents, that nicotine was both addictive and destructive. And insofar as they have pretended that they did not know that, that is wrong.

I think some of these companies have said, "We don't want teenagers to smoke", but they have consciously directed their advertising strategies to make it appealing to young people. And not just Joe Camel, which was obvious, but a lot of other things as well. I think those things are wrong.

And what I want the tobacco companies to do is stop doing the wrong thing and start doing the right thing. I think they ought to come in here and support this - these restrictions. I think they ought to ask Congress to enact them into law now. If they don't want the FDA to regulate them, let's enact the law now.

And I think that we ought to start the very next day on this campaign together. If the tobacco companies really don't want kids to smoke, we can do this together.

Q: Are you going to try to bring back the cigarette tax? California has had a lot of success with that in their state.

President Clinton: Well, this Congress would not adopt that. I have had a number of 
people who've come from tobacco counties suggest that some of the cigarette tax ought to be devoted to helping the farmers who want to convert their farm land to other purposes, to some sort of buy-out program.

The bulk of the cigarette tax is available to the states, and a lot of the states now are passing cigarette taxes to help to pay for the health care bills of people who are suffering from tobacco related illnesses. And I don't want to see the Congress and the federal government crowd that out. So when I proposed a tobacco tax before, it was to pay for health care. That's not going to happen this year.

Q: Right now, advertising is written off as a business expense and that means the public pays in some fashion for all advertising, including cigarette advertising. Would you consider getting rid of the tax deduction for cigarette advertising?

President Clinton: You're the first person who's ever suggested it to me. I'd never thought of that. That's an interesting idea.

Q: So I'll give you a few minutes to absorb it and I'll come back. (Laughter)

President Clinton: That's an interesting idea. I've never thought of that.

Q: Because I think a lot of people would be offended by the idea of paying for an unhealthy product to advertise and garner more smokers through it. But I'll let you dwell on it.

Not only do you want to regulate tobacco products, but you're also in favor of regulating how they're marketed. And I was wondering, how far do you plan to go? When a musician sits down to talk with me and they're smoking a cigarette, should I not air that footage on MTV? Should I ask Keith Richards to put out his cigarette before he does an interview with me? Should this go for all television? Because a lot of young people watch MTV.

President Clinton: I think that's a decision for you to make. I think you should ask him to put it out because I think there are a lot of young people...

Q: It is Keith Richards.

President Clinton: I know. (Laughter) And I know he's an icon - for me, too.

Q: I don't know if he - his heart might stop if he doesn't have a cigarette.

President Clinton: That's the great thing about their endurance, you know. But that's a decision that each network, each interviewer, they'll have to make. Let me just say this: I believe very strongly in the first amendment and the right to free speech, free association, and freedom of religion. I believe in a very broad interpretation of it. But I believe that we should be restricting advertising directed at children because it's illegal to sell cigarettes to children. So, therefore, if it's illegal to sell cigarettes to children, it can't be illegal to stop the advertising directed at children. So that's what my focus is.
In terms of the interviews and everything, I would hope every American adult, even those who smoke, would think - as I had to when I became President and I had this occasional bad habit of having my cigar once in a while about not doing it in public, not doing it around children, not setting a bad example. I think we adults have a responsibility to try to set a good standard for our young people and to basically say everybody's got a lot of problems, but being self-destructive is not a way to deal with them.

Q: Mr President, I want to say this as politely as I can, but I think a lot of our viewers are going to be wondering why should they listen to you about this issue?

President Clinton: Well, they don't have to listen to me about this issue. What we're going to do is change the law. But I'll tell you why they should listen to me or to anybody else. I would say that if they wanted to listen to me, don't listen to me, look at the medical research, look at the evidence. This is about their lives, not mine. I've lived most of my life. Their lives are ahead of them. And the reason they should listen to me is that the evidence is on my side, not just because I'm President. We know that nicotine in cigarettes and smokeless tobacco is addictive, is destructive, and will shorten the lives of one out of three people who starts smoking on a regular basis. We know that.

So what they should do is say, "Okay, here's the evidence. Now, what kind of life do I want to live?" Ultimately, it's going to be their decision because even if the law keeps cigarettes away from them in the near term, soon they'll turn 18 and they'll be able to do whatever they want to do. They have to make these decisions. But I think my job - what I'm trying to do here every day, with the economy, with saving the college loan program, with trying to preserve the environment from this awful assault that the Congress is making on it - is to give the young people of our country a good country to grow up into and a good life to look forward to. Then they have to make a decision about how to live that life.

And what those of us who are older are supposed to do is to say, "Here's what we think will maximise your choices. Here's what we think will give you the chance to live up to the fullest of your abilities." And that's what I hope they'll listen to, because the evidence is on my side. I'm not just preaching here, I have all this evidence.

Q: Right. Right. It's not like you don't have enough things to do already.

President Clinton: But this is a big deal. Everything I try to do here--(for example) trying to save the college loan program from attack and trying to preserve the environmental protections we have in this country-why would I do that? Because I want my child and our grandchildren and all the young people coming up to enjoy a good life. That still requires all these individuals who are watching us to make decisions about how they're going to live. And being addicted to tobacco is not a 
smart thing to do if you want to have a long, full good life. It's a huge roll of the dice.

I never will forget a few years ago having to speak at the funeral of a very close friend of mine, a man that had literally no other vices. He was one of the most perfect human beings I ever knew. But he smoked a couple of packs of cigarettes a day and he died of lung cancer two and a half years after he had his last cigarette because it takes that long to clean out your lungs.

Q: Wow.

President Clinton: And he was younger than me. I never got over it. I never will get over it.

Q: I wanted to ask you if you were-well, Jerry Garcia has affected millions of Americans.

President Clinton: Me, too.

Q: Were you a fan? Have you ever been to a Grateful Dead show? And why do you think he affected so many people of different backgrounds and generations?

President Clinton: Well, first of all, he was just a great talent. I mean, he was really - he was a genius. And I was really pleased to see the Grateful Dead have one more great run around the country in the last couple of years and see all these young teenagers gravitating to a group that all of us liked 20 or more years ago. He had a great gift. And he even wound up putting out that line of ties. He had great ties. I would go around wearing Jerry Garcia ties and giving them away to people.

So I was very sad when he died.

But he also had a terrible problem that was a legacy of the life he lived and the demons he dealt with. And I would hope that all of us who loved his music and valued his contributions would also reflect on the consequences of, again, really self destructive behavior. ${ }^{\star}$ The lesson of Jerry Garcia's life is that he made a great contribution and he had at least two generations of Deadheads, you know.

Q: Is Chelsea a fan at all? Has she ever gone to a show?

President Clinton: Yes, very much. But she and I were talking - we had a long talk about it the other day, right before I left to come to the office. She called me on the phone. She's out of town, and she called me on the phone, and we were talking about it. And she was talking about all the kids in her school who are great fans of Jerry Garcia, and we had a long talk about it.

But I would hope that as we mourn him and sort of feel grateful for what he did, young people should say, "I'm not going to die that way. I'm not going to die in a clinic with a drug addiction. I'm not going to do it." You don't have to have a destructive lifestyle to be a genius and make a contribution. You don't have to do that.

Q: Any thoughts on the advertising, cigarette advertising being a tax deduction?

President Clinton: I'll look into it. It's an interesting idea. Nobody ever even raised it to me before. Maybe you should be here making public policy. That's great.

Q: I don't think so. I think I'm quite busy. I wouldn't want your job.

President Clinton: Thanks.

Q: You do a good job, though. Thank you.

* Ferry Garcia, bandleader of the Grateful Dead for three decades, died of a heart attack on 9 August 1995, at the age of 53. In addition to his long history of illicit drug use, his cigarette smoking (see page 309) and weight are likely to have contributed to the cause of death. - ED

\section{FDA Press Releases, 10 August 1995}

August 10, 1995

Contact: FDA Press Office (301) 443-1130

\section{Children and tobacco: the facts}

The Clinton Administration is proposing a comprehensive and coordinated set of measures to reduce significantly the number of children and adolescents who become addicted to nicotine in cigarettes and smokeless tobacco (snuff and chewing tobacco). Children are becoming addicted to these products, with more than $80 \%$ of smokers beginning to smoke by the age of 18 .

Smoking is the leading preventable cause of death in the United States, and health care costs associated with smoking soared to more than $\$ 50$ billion in 1993, according to the Centers for Disease Control. While the proposed measures will continue to maintain the legal status of cigarettes and smokeless tobacco products for adults, they will reduce the easy access and strong appeal for children.

Preventing children from smoking is the key to reducing the deadly toll of smoking. The Clinton Administration's plan will help parents provide their children with an environment in which to grow up healthy. 
A PAEDIATRIC DISEASE

Children are becoming addicted to nicotine. The average teenage smoker starts at $14 \frac{1}{2}$ years old and becomes a daily smoker before 18 . More than $80 \%$ of all adult smokers had tried smoking by their 18th birthday and more than half of them had already become regular smokers by that age. Studies show that if people do not begin to smoke as teenagers or children, it is unlikely they will ever do so.

Each and every day, another 3000 young people become regular smokers, and nearly 1000 of them will eventually die as a result of their smoking. Currently, more than three million children and adolescents smoke cigarettes, and one million adolescent boys currently use smokeless tobacco. Smoking by young people is rising sharply. Between 1991 and 1994, the percentage of eighth graders who smoke increased $30 \%$, and the percentage of tenth graders who smoke increased $22 \%$.

Children tend to vastly underestimate the likelihood that they will become addicted to these products. Although only $5 \%$ of daily smokers surveyed in high school said they would definitely be smoking five years later, close to $75 \%$ were smoking seven to nine years later. A survey conducted in 1992 found that approximately two thirds of adolescents who smoked said they wanted to quit and $70 \%$ said they would not start smoking if they could make that choice again.

SMOKING : LEADING CAUSE OF AVOIDABLE, PREMATURE DEATH

Tobacco use takes enormous, deadly toll each year. Tobacco products are responsible for more than 400000 deaths each year due to cancer, respiratory illness, heart disease, and other health problems. Cigarettes kill more Americans each year than AIDS, alcohol, car accidents, murders, suicides, illegal drugs, and fires combined. Smokers who die as a result of smoking would have lived on average 12 to 15 years longer if they had not smoked.

The health care costs associated with tobacco use are rising. The Centers for Disease Control estimated that in 1993 the health care costs associated with smoking totalled $\$ 50$ billion: $\$ 26.9$ billion for hospital costs; $\$ 15.5$ billion for doctors; $\$ 4.9$ billion in nursing home costs; $\$ 1.8$ billion for prescription drugs; and $\$ 900$ million for home health care expenditures. The Office of Technology Assessment calculated the social costs attributable to smoking in 1990 at $\$ 68$ billion. That calculation was based on $\$ 20.8$ billion in direct health care costs and $\$ 6.9$ billion in lost productivity from disabilities and $\$ 40.3$ billion in lost productivity from premature deaths.
Children and tobacco: the problem EASY ACCESS

Despite state laws prohibiting the sale of tobacco to minors, children can easily buy these products. One study estimated that teenagers annually consume 516 million packs of cigarettes and 26 million containers of chewing tobacco. A review of 13 studies of over-the-counter sales found that on average, children and adolescents were able to successfully buy tobacco products $67 \%$ of the time.

- Vending machines are a primary source of tobacco products for young smokers. A study by the vending machine industry found that $22 \%$ of 13 year old smokers use vending machines compared with 2 percent of 17 -yearold smokers. The 1994 Surgeon General's Report found that young people were able to buy cigarettes in vending machines an average of 88 percent of the time.

- Mail order sales provide no sure way of verifying age. Current industry practice only asks the consumer to provide a birth date or check box to verify age.

- Self-service displays allow children to easily obtain tobacco products. The Institute of Medicine, in its landmark 1994 report, "Growing Up Tobacco Free", concluded that placing tobacco products "out of reach reinforces the message that tobacco products are not in the same class as candy or potato chips".

- Free samples are obtained by children, including those in elementary school, despite industry code prohibiting distribution to anyone under 21. Free samples occur on street corners, at shopping malls, and at sporting events. A New Jersey survey found that one third of high school students who were smokers or ex-smokers reported receiving free samples before age 16 .

\section{APPEALING TO CHILDREN}

Advertising and promotional activities can greatly influence a young person's decision to smoke or use smokeless tobacco products. Awareness of tobacco products and messages is very high among even the youngest children. Studies show that $30 \%$ of 3 year olds and $91 \%$ of 6 year olds could identify "Joe Camel" as a symbol for smoking. The Centers for Disease Control recently reported that $86 \%$ of underage smokers who purchase their own cigarettes purchase one of the three most heavily advertised brands: Marlboro, Camel, and Newport.

- Tobacco products are among the most heavily advertised products in the United States. In 1993, the tobacco industry spent $\$ 6.2$ billion on advertising and promoting cigarettes and smokeless tobacco. Tobacco advertising expenditures have increased more than $1500 \%$ between 1970 (the year before television and radio advertising was banned) and 1992.

- Promotion of tobacco products through non-tobacco items such as $\mathbf{T}$ - 
shirts, hats, and gym bags and through sponsorship of events is reaching children. A 1992 Gallup survey found that half of adolescent smokers and one quarter of adolescents who do not smoke owned at least one tobacco promotional item such as a $\mathrm{T}$ shirt, cap, sporting good, or lighter. Another report found that one out of four 12 and 13 year olds own one of these items. Used or worn by young people, these become "walking billboards", promoting these products in schools and other locations where tobacco advertising is usually prohibited. Sponsorship of events such as tennis tournaments, car races, and rodeos associate tobacco products with excitement and glamour, and provide a way for tobacco brands to be advertised on television despite the broadcast advertising ban.

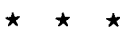

\section{Children and tobacco: the proposal}

The Clinton Administration is proposing a comprehensive and coordinated plan to reduce smoking by children and adolescents by $50 \%$. It builds on previous actions taken by Congress and others such as the ban on television advertising and state laws to prohibit the sale or use of tobacco by children. It follows recommendations by the American Medical Association and the Institute of Medicine. Experts have consistently recommended that the keys to achieving the goal are: reducing access and limiting the appeal for children. This ambitious initiative accomplishes that objective, while preserving the availability of tobacco products for adults. The proposals announced today include:

REDUCING EASY ACCESS BY CHILDREN

- Require age verification and face-to-face sale and eliminate mail order sales, vending machines, free samples, self-service displays, and sale of single cigarettes ("loosies") and packages with fewer than 20 cigarettes ("kiddie packs").

REDUCING APPEAL TO CHILDREN

- Ban outdoor advertising within 1000 feet of schools and playgrounds. Permit black and white text only advertising for all other outdoor advertising, including billboards, signs inside and outside of buses, and all point-of-sale advertising.

- Permit black and white text only advertising in publications with significant youth readership (under 18). (Significant readership means more than $15 \%$ or more than two million. No restrictions on print advertising below these thresholds.)

- Prohibit sale or giveaway of products like caps or gym bags that carry cigarette or smokeless tobacco product brand names or logos. Prohibit exchange of non-tobacco products for proof of purchase of tobacco products.

- Prohibit brand name sponsorship of sport- ing or entertainment events, but permit it in the corporate name.

- Require industry to fund $(\$ 150$ million annually) a public education campaign to prevent kids from smoking.

$\star \star \star \star$

\section{Children and tobacco: what others say}

"I figure if it's really so bad for you, they wouldn't be selling them everywhere. I mean, you walk into the Stop ' $N$ ' Go, and there's a whole wall of them right up front at the cash register. If they were really that bad for you, they'd make them less accessible."

- Brian Grindele, 18

The New York Times, fuly 30, 1995

"Given all that we know, the scientific case for protecting children from tobacco is indisputable. The moral imperative to act is imperative ...this is not a Democratic or a Republican issue. It is a bipartisan, pro-child, pro-family, pro-health issue."

- President fimmy Carter

USA Today, August 3, 1995

"The tobacco industry continues to insist that smoking is a simple matter of individual rights and adult choice. If that were true, I would be on their side. But we're not talking about adults. We're talking about keeping an addictive and lethal substance out of the hands of children. Neither the FDA nor anyone else is talking about prohibiting adults from smoking."

- Former US Senator Barry Goldwater Wall Street fournal, August 8, 1995

"The American Medical Association reminds physicians, the public, and politicians that the damning evidence against tobacco makes opposition to its use a pressing, nonpartisan public health issue.'

- Editorial

Fournal of the American Medical Association, fuly 19, 1995

"We believe that current tobacco regulations, limited primarily to a ban on television advertising and the promotion of warning labels on packages, are insufficient in protecting America's children. The FDA should have authority to control tobacco by placing new limits on tobacco advertising, creating stricter licensing regulations for vendors, and banning cigarette vending machines."

- American Public Health Association

Letter to President Clinton from APHA fuly 13, 1995

"What is most significant about teens and smoking, however, is that, from all indications, smoking is an addiction that is typically initiated during the teenage years or not at all. For the great majority of smokers, this addiction begins before they are old enough to purchase tobacco lawfully. In fact, 75 percent 
of all adult smokers report that they became addicted to tobacco before they were 18 years old. Very few smokers take up smoking for the first time as adults. If youth access can be controlled effectively, and the decision whether to smoke can be delayed until adulthood, then, over time, smoking will be greatly reduced as a major addiction in our society.'

_"No Sale: Youth, Tobacco and Responsible Retailing"

Working Group of State Attorneys General December 1994

"The nation must commit itself to a vigorous public health initiative in tobacco control... the nation cannot reasonably expect to eliminate tobacco related disease and death by 2010. However, by putting a youth centered prevention strategy at the center of tobacco control efforts, and by implementing the initiatives proposed (to that end) in this report, the nation can take a firm and resolute step on that path."

- "Growing Up Tobacco Free"

Institute of Medicine, September 1994

"The concept - pediatric disease - qualifies as an epiphany, given the acknowledged authority of society over a minor. $\mathrm{He} /$ she has to go to school, has to wait until a certain age before being allowed to drive, to vote, to drink beer. It yields no substantial libertarian ground to add to the list of enforcement mechanisms designed to dissuade the 15 year old from taking up a habit that brings on premature and painful death."

- William F. Buckley $\mathfrak{f r}$

Syndicated columnist, March 1995

" ... from a public-health standpoint, keeping kids away from cigarettes is the single most effective way to fight the nation's leading preventable cause of death."

- "Hooked on Tobacco: The Teen Epidemic" Consumer Reports, March 1995

\section{Further reading :}

The global tobacco epidemic. Scientific American, May 1995.

The nicotine connection. Chemical and Engineering News, November 28, 1995.

Hooked on tobacco: the teen epidemic. Consumer Reports, March 1995.

Nicotine addiction in young people. $N$ Engl f Med, July 20, 1995.

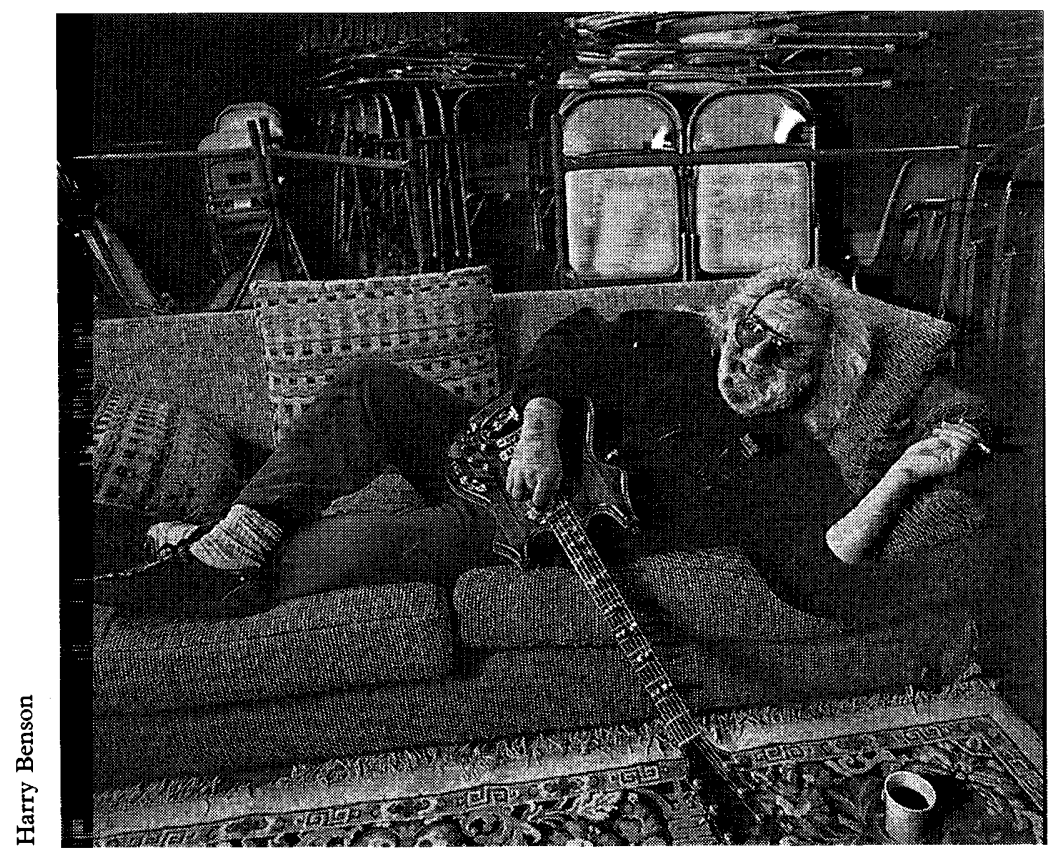

Ferry Garcia, bandleader of the Grateful Dead for three decades, died of a heart attack on 9 August 1995, at the age of 53. In addition to his long history of illicit drug use, his cigarette smoking and weight are likely to have contributed to the cause of death. 